\title{
DAMPAK PENINGKATAN KONSUMSI KARET ALAM DOMESTIK TERHADAP KESEJAHTERAAN PETANI KARET INDONESIA
}

\author{
Linda Purwaningrat $^{1^{*}}$, Tanti Novianti ${ }^{2}$, Saktyanu K Dermoredjo ${ }^{3}$ \\ ${ }^{1}$ Ilmu Ekonomi Pertanian, sekolah Pascasarjana, IPB University, Bogor, \\ Kampus IPB, Dramaga Bogor 16680 Jawa Barat \\ ${ }^{2}$ Fakultas Ekonomi dan Manajemen, IPB University, \\ Kampus IPB, Dramaga Bogor 16680 Jawa Barat \\ ${ }^{3}$ Pusat Sosial Ekonomi dan Kebijakan Pertanian, Kementerian Pertanian, \\ Jl. Tentara Pelajar 3B, Bogor Jawa Barat \\ *Corresponding author: linda.purwaningrat@gmail.com
}

\begin{abstract}
Rubber is a people's commodity that contributes greatly to the Indonesian economy. However, the price of natural rubber fluctuates with a downward trend, thus affecting state income and the welfare of Indonesian rubber farmers. Therefore, the natural rubber producing countries in the ITRC forum agreed to increase domestic natural rubber consumption in their respective countries as an effort to stabilize the price of rubber in the world. This policy was later referred to as the Demand Promotion Scheme (DPS). This study aims to see the impact of the application of DPS as a domestic natural rubber trade policy on the welfare of Indonesian rubber farmers. The analysis uses an econometric model in the form of a system of simultaneous equations which is estimated by the Two-Stage Least Squares (2SLS) method using the 1992-2017 annual data series. The results of this study indicate that the implementation of policies to increase domestic natural rubber consumption can improve the welfare of Indonesian rubber farmers.
\end{abstract}

Keywords: econometric analysis, natural rubber, domestic consumption

\begin{abstract}
Abstrak: Karet merupakan komoditi rakyat yang berkontribusi besar bagi perekonomian Indonesia. Namun harga karet alam berfluktuasi dengan tren menurun, sehingga mempengaruhi pendapatan negara dan kesejahteraan petani karet Indonesia. Oleh sebab itu, negara-negara produsen karet alam dalam forum International Tripartite Rubber Council bersepakat untuk melakukan peningkatan konsumsi karet alam domestik di negara masing-masing sebagai upaya stabilisasi harga karet di dunia. Kebijakan ini kemudian disebut sebagai Demand Promotion Scheme. Penelitian ini bertujuan untuk melihat dampak penerapan Demand Promotion Scheme sebagai kebijakan perdagangan karet alam domestik terhadap kesejahteraan petani karet Indonesia. Analisis menggunakan model ekonometrik dalam bentuk sistem persamaan simultan yang diestimasi dengan metode Two Stage Least Squares menggunakan data series tahunan 1992-2017. Hasil penelitian ini menunjukkan bahwa penerapan kebijakan meningkatkan konsumsi karet alam dalam negeri mampu meningkatkan kesejahteraan petani karet Indonesia.
\end{abstract}

Kata Kunci: analisis ekonometrik, karet alam, konsumsi domestik

\section{PENDAHULUAN}

Karet alam merupakan salah satu komoditas perkebunan yang memiliki pasar yang cukup luas dalam perdagangan internasional karena dibutuhkan sebagai bahan baku berbagai industri. Indonesia merupakan negara dengan potensi produksi karet alam yang sangat besar, dimana pada tahun 2018 total produksi karet alam Indonesia mencapai 3,77 juta ton pada 
tahun 2018 atau $26 \%$ dari total produksi dunia (Gabungan Perusahaan Karet Indonesia, 2019).

Karet alam sendiri sering disebut sebagai komoditas perkebunan rakyat karena besarnya kontribusi perkebunan rakyat dalam produksi karet nasional. Berdasarkan data dari Direktorat Jenderal Perkebunan (2018), sebesar $84,5 \%$ areal karet merupakan perkebunan rakyat yang menyumbang sekitar $82,3 \%$ dari total produksi karet alam Indonesia. Oleh sebab itu, permasalahan karet alam terutama akibat adanya fluktuasi harga karet dunia sangat mempengaruhi kesejahteraan 2,5 juta petani karet Indonesia. Hal tersebut karena berdasarkan data dari Indonesia Eximbank Institute (2019), karet alam Indonesia saat ini sebesar $85 \%$ diprioritaskan pada pasar ekspor sehingga harga karet alam Indonesia dipengaruhi dan ditentukan oleh perkembangan harga di luar negeri.

Sementara itu, harga karet alam dunia sendiri sangat berfluktuasi. Berdasarkan data dari Pusat Data dan Sistem Informasi Pertanian (2017), harga karet internasional telah mengalami tekanan mulai dari 2011 ketika aktivitas ekonomi global lemah (yang berdampak negatif pada industri otomotif) serta melimpahnya pasokan karet alam. Harga karet alam dunia yang cenderung tertekan di tingkat yang sangat rendah selama beberapa tahun terakhir membuat petani karet rakyat yang memproduksi lebih dari $82 \%$ karet alam Indonesia turut terkena dampaknya. Mengikuti fluktuasi harga dunia, harga karet di tingkat petani juga mengalami tren penurunan. Pada tahun 2008 harga karet di Indonesia mengalami penurunan hingga mencapai $\mathrm{Rp}$ $6.050 / \mathrm{kg}$, tahun 2012 mencapai Rp $11.333 / \mathrm{kg}$, namun terus mengalami penurunan, dimana pada tahun 2015 harga mencapai $10.852 / \mathrm{kg}$ dan di awal tahun 2019 harga hanya berkisar di angka Rp 6.000/kg (Kementan, 2020). Menurut Welatama (2017), penurunan harga karet di tingkat petani berdampak pada penurunan daya beli dan kesejahteraan petani.

Fluktuasi harga merupakan permasalahan umum pada pemasaran produk pertanian. Harga komoditas pertanian pada umumnya sangat dipengaruhi oleh keseimbangan antara penawaran dan permintaan komoditas tersebut. Menurut Simatupang (2007), fluktuasi harga tersebut seringkali lebih merugikan petani daripada pedagang karena petani umumnya tidak dapat mengatur waktu penjualannya untuk mendapatkan harga jual yang lebih menguntungkan. Disamping itu fluktuasi harga yang tinggi juga memberi peluang kepada pedagang untuk memanipulasi informasi harga di tingkat petani sehingga transmisi harga dari pasar konsumen kepada petani cenderung bersifat asimetris dalam pengertian jika terjadi kenaikan harga di tingkat konsumen maka kenaikan harga tersebut tidak diteruskan kepada petani secara cepat dan sempurna, sebaliknya jika terjadi penurunan harga.

Permasalahan fluktuasi harga karet ini sebagai hal yang krusial karena mempengaruhi pendapatan negara dan kesejahteraan petani karet Indonesia. Untuk itulah Indonesia memiliki kepentingan besar atas setiap perubahan harga karet alam. Oleh sebab itu, pemerintah Indonesia bekerja sama dengan negara-negara produsen karet lainnya membentuk forum kerjasama yang kemudian dikenal dengan sebutan International Tripartite Rubber Council (ITRC). Dalam upaya ITRC untuk stabilisasi harga karet alam dunia, ITRC sepakat melakukan Demand Promotion Scheme (DPS). Skema ini dilakukan dengan meningkatkan konsumsi karet alam domestik dengan tujuan untuk mengendalikan harga karet di tingkat petani.

Berdasarkan permasalahan diatas, penelitian ini bertujuan untuk menganalisis dampak penerapan peningkatan konsumsi karet alam domestik terhadap kesejahteraan petani karet Indonesia. Hasil penelitian ini diharapkan dapat memberikan rekomendasi kepada pemerintah selaku pemangku kebijakan dalam meningkatkan kesejahteraan petani.

\section{METODE PENELITIAN}

Adanya peningkatan permintaan domestik di pasar karet alam domestik akan menyebabkan pergeseran kurva permintaan domestik dari D ke D' sehingga akan meningkatkan harga karet alam di tingkat produsen (petani). Peningkatan harga tersebut akan mendorong petani untuk meningkatkan produksi karet alamnya dari Q ke Q'. Sehingga pada akhirnya surplus produsen sebagai dampak peningktan permintaan domestik adalah $\mathrm{a}+\mathrm{b}$ (Gambar 1). 


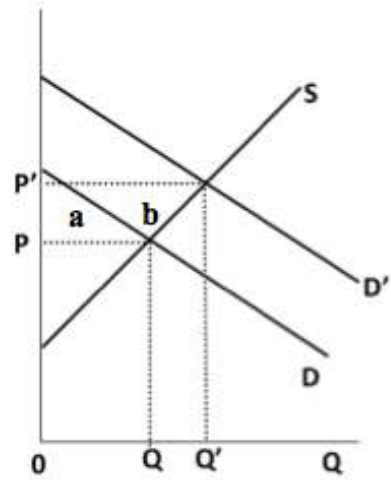

Gambar 1. Dampak peningkatan permintaan domestik di pasar karet alam domestik Sumber : Dikembangkan dari Purba (2018)

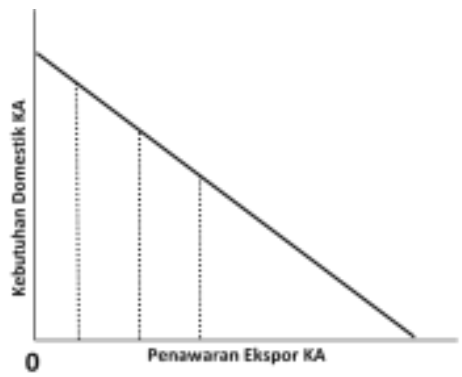

Gambar 2. Hubungan kebutuhan domestik dan penawaran ekspor karet alam Indonesia

Sumber : Dikembangkan dari Nicholson (1978)

Namun demikian, permintaan pasar karet alam Indonesia umumnya terdiri dari permintaan industri dalam negeri dan permintaan oleh eksportir yang selanjutnya menjadi penawaran ekspor. Oleh sebab itu, kebijakan ITRC untuk meningkatkan permintaan karet alam dalam negeri akan berdampak pada menurunnya jumlah penawaran kepada eksportir karena adanya kompetisi terhadap penawaran karet alam domestik (Gambar 2). Penjelasan dari kurva tersebut adalah, semakin tinggi permintaan domestik karet alam maka semakin rendah penawaran ekspornya.

Sehingga adanya kebijakan peningkatan permintaan domestik akan menurunkan penawaran ekspor karet alam dan berdampak pada perdagangan dunia. Selanjutnya dapat dilihat pada Gambar 3, adanya penurunan produksi di pasar domestik akan menyebabkan menurunkan total penawaran ekspor karet alam Indonesia di pasar dunia dari SA ke S'A sehingga menyebabkan adanya peningkatan harga karet alam di pasar dunia dari titik Pw ke P'w. Sehingga di negara eksportir akan berdampak pada penurunan penawaran ekspor dari qc - qp menjadi q'c - q'p. Di negara importir adanya peningkatan harga didunia akan menyebabkan penurunan permintaan impor dari Qc - Qp menjadi Q'c - Q'p. Adapun berdasarkan asumsi bahwa pasar karet alam dunia terintegerasi dengan baik sehingga adanya peningkatan harga di pasar dunia juga dapat ditransmisikan ke harga di tingkat domestik.

Data yang digunakan adalah hasil simulasi dari analisis simultan dengan model matematisnya seperti pada Lampiran 1, dimana masing-masing persamaan dalam penelitian diestimasi dengan menggunakan metode estimasi Two-Stages Least Squares (2SLS). Metode estimasi digunakan untuk mengestimasi parameter produksi, permintaan domestik, penawaran ekspor, harga karet alam Indonesia di tingkat produsen dan eksportir, penawaran ekspor negara ITRC lainnya, harga ekspor negara ITRC lainnya, permintaan impor oleh negara-negara importir dan harga impor karet alam di negara importir. Selanjutnya, dilakukan simulasi model yang berguna untuk menganalisis dampak penerapan peningkatan konsumsi karet alam domestik (DPS) terhadap kesejahteraan petani karet Indonesia. Selanjutnya pengolahan data dilakukan dengan menggunakan program komputer Statistical Analysis Software / Econometric Time Series (SAS/ETS) versi 9.4. Dengan berdasarkan analisis tersebut diperoleh dasar-dasar analisis lanjutannya sebagai berikut:

1. Berdasarkan kriteria statistiknya, hasil estimasi model perdagangan karet alam Indonesia, negara-negara ITRC dan dunia cukup baik. Terdapat 17 persamaan $(89,5$ $\%)$ mempunyai koefisien determinasi di atas $70 \%$ dan 2 persamaan $(10,5 \%)$ mempunyai koefisien determinasi lebih kecil dari $70 \%$.

2. Adapun rentang $\mathrm{R}^{2}$ dari seluruh persamaan perilaku yaitu diantara 48 - $98 \%$. Hal ini berarti keragaman masing-masing variable endogen dapat dijelaskan cukup baik oleh masing-masing variabel penjelas pada masing-masing persamaan perilaku. Variabel penjelas pada masing-masing persamaan secara bersama-sama nyata menjelaskan keragaman variabel endogen yang ditunjukan oleh nilai statistik $F$ yang nyata pada taraf $1 \%$. 


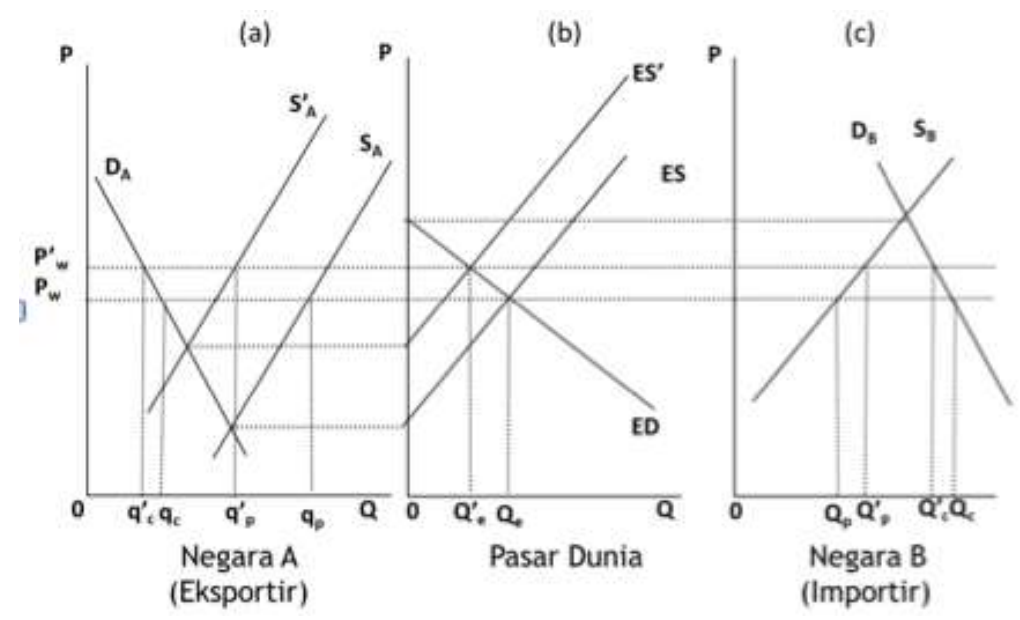

Gambar 3. Dampak penurunan penawaran ekspor akibat peningkatan permintaan domestik di negara eksportir terhadap perdagangan

Sumber : Dikembangkan dari Tweeten (1992)

3. Untuk mengetahui bahwa pengaruh masingmasing variable penjelas tersebut signifikan secara statistik atau tidak, ditunjukan oleh nilai statistik-t pada taraf nyata $\alpha$ menjunjukkan bahwa pengaruh masingmasing variabel penjelas terhadap variabel endogennya pada setiap persamaan perilaku secara umum menunjukkan pengaruh yang nyata pada taraf $5 \%, 10 \%$, dan $15 \%$. Kriteria ekonometrik dilakukan dengan uji multikoliniaritas menggunakan Variance Inflation Factor (VIF). Hasil estimasi menunjukkan nilai VIF yang lebih besar dari 10 hanya 2 persamaan, sehingga tidak terdapat masalah multikolinearitas yang serius (Sitepu dan Sinaga 2018).

4. Validasi model perdagangan karet alam di Indonesia, negara ITRC lainnya dan dunia dilakukan pada periode tahun 2007-2017 dengan tujuan dapat melihat gambaran kondisi perdagangan karet alam Indonesia, negara ITRC lainnya dan dunia. Berdasarkan hasil validasi model, statistik validasi menunjukan bahwa sebagian besar dari variabel endogen yang terdapat dalam model memiliki RMSPE dan U-Theil's yang cukup kecil. Dari 24 variabel endogen, hanya 3 variabel yang memiliki RMSPE lebih besar dari $30 \%$, sementara variabel endogen lain sebanyak $87,5 \%$ memiliki RMSPE lebih kecil dari 30\%. Statistik validasi untuk nilai U-Theil's menunjukan kisaran antara 0,0427 - 0,4446, dengan nilai U-Theil lebih kecil dari 0,3 sebanyak 91,7\%. Hal ini menunjukkan bahwa selama periode simulasi historis tahun 2007 - 2017 nilai prediksi variabel endogen cukup dekat dengan nilai aktualnya. Oleh karena itu, model baik digunakan untuk analisis simulasi dampak kebijakan ITRC terhadap perkembangan pasar karet alam Indonesia, negara ITRC lainnya dan dunia.

Berdasarkan hasil analisis yang telah dilakukan akan dilakukan analisis lanjutan terhadap perubahan tingkat kesejahteraan. Adapun perubahan tingkat kesejahteraan produsen dianalisis dari hasil simulasi kebijakan sehingga dapat diketahui bagaimana perubahan distribusi kesejahteraan sebagai akibat dari kebijakan tersebut. Analisis perubahan kesejahteraan produsen dapat dihitung dengan menggunakan rumus berikut (Sinaga, 1989):

$$
\begin{aligned}
\triangle P S= & Q P K I b(P P K I s-P P K I b)+1 / 2(Q P K I s- \\
& Q P K I b)(P P K I s-P P K I b)
\end{aligned}
$$

Keterangan:

$$
\begin{array}{ll}
P S & =\text { surplus produsen } \\
Q P K I & =\text { produksi karet alam Indonesia } \\
P P K I & =\text { harga riil karet alam Indonesia di } \\
& \text { tingkat produsen } \\
b & =\text { nilai dasar } / \text { basis } \\
s & =\text { nilai simulasi }
\end{array}
$$


Data yang digunakan dalam bentuk time series tahunan dengan rentang waktu dari tahun 1992 - 2017. Data yang digunakan bersumber dari Kementerian Pertanian, Badan Pusat Statistik (BPS), Gabungan Pengusaha Karet Indonesia (GAPKINDO), International Rubber Consortium Limited (IRCo), International Rubber Study Group (IRSG), Bank Indonesia (BI), Kementerian Perdagangan, International Trade Centre (ITC), United Nation Commodity Trade (UN COMTRADE), World Develoment Indicator (www.worldbank.org) dimana data yang digunakan menurut tahun kalender.

\section{HASIL DAN PEMBAHASAN}

Informasi awal yang dapat dikemukakan bahwa faktor-faktor yang memengaruhi permintaan karet alam domestik adalah harga karet alam di tingkat produsen, harga karet sintetis, Gross Domestic Bruto (GDP) Indonesia, dan karet alam domestik tahun sebelumnya. Harga karet alam di tingkat produsen semakin tinggi harga karet alam di tingkat produsen maka akan semakin rendah permintaan domestiknya. Sebaliknya, karet sintetis memiliki gambaran semakin tinggi harga karet sintetis maka permintaan terhadap karet alam akan meningkat (Harder, 2018), sehingga karet sintetis dan karet alam merupakan polimer yang dapat saling mensubtitusi hingga tingkat tertentu, meskipun terdapat faktor-faktor teknis dan spesifikasi pada karet alam yang tidak dapat direplikasi oleh karet sintetis. Disisi lain, GDP juga memiliki hubungan yang positif dengan permintaan karet alam domestik, yang artinya apabila GDP meningkat dan perekonomian negara membaik maka permintaan karet alam domestik akan naik. Hal tersebut disebabkan oleh sebagian besar permintaan karet alam domestik ditujukan untuk kebutuhan bahan baku industri yang erat kaitannya dengan tren positif perekonomian Indonesia.

Sementara itu, penawaran ekspor karet alam Indonesia ke negara-negara tujuan ekspor (Tiongkok, AS dan Jepang), dipengaruhi oleh jumlah produksi karet alam Indonesia, harga ekspor karet alam, nilai tukar rupiah terhadap dolar Amerika, serta permintaan karet alam domestik. Dengan pengaruh nyata pada taraf $5 \%$, jumlah produksi karet alam Indonesia mempunyai pengaruh yang cukup besar bagi eksportir untuk pengambilan keputusan perilaku penawaran ekspor karet alam ke. Hal ini didukung dalam penelitian sebelumnya oleh Tety (2002) yang menyatakan bahwa jumlah ekspor karet alam Indonesia responsif terhadap perubahan jumlah produksi karet di dalam negeri. Selain itu, harga ekspor karet Indonesia memberikan pengaruh pada perilaku penawaran ekspor karet Indonesia. Hal ini sesuai dengan penelitian Prabowo (2017) yang menyebutkan bahwa harga riil ekspor karet alam Indonesia mempengaruhi keputusan eksportir karet alam Indonesia untuk melakukan penawaran ekspor. Nilai tukar rupiah terhadap US\$ juga memberikan pengaruh pada perilaku penawaran ekpor karet alam. Hasil ini sesuai dengan penelitian sebelumnya, yang menyebutkan bahwa nilai tukar (Rp/USD) secara parsial memiliki pengaruh positif dan signifikan terhadap volume ekspor Indonesia (Ginting, 2013). Adapun permintaan domestik juga memberikan pengaruh pada perilaku ekspor karet alam dengan hubungan yang negatif. Hal ini berarti, adanya peningkatan konsumsi karet alam domestik, akan menyebabkan penurunan jumlah ekspor karet alam Indonesia.

Hasil penelitian juga menegaskan hubungan antara harga karet alam di tingkat produsen dengan harga ekspor karet alam adalah positif, artinya ketika harga ekspor karet alam naik, maka harga karet alam di tingkat produsen juga akan naik. Hubungan harga ekspor dan harga di tingkat produsen berdasarkan asumsi bahwa pasar karet alam terintegrasi dengan baik, sehingga harga ekspor karet alam di transmisikan kepada harga di tingkat petani. Selain itu, harga karet alam di tingkat produsen juga di pengaruhi oleh nilai tukar dan permintaan karet alam domestik. Hal ini sesuai dengan penelitian sebelumnya yaitu perubahan jumlah permintaan karet di pasar domestik berpengaruh signifikan dan responsif terhadap harga karet alam di tingkat produsen (Tety, 2002).

Dalam hasil estimasi terhadap perilaku harga ekspor karet alam diketahi bahwa total penawaran ekspor memiliki hubungan yang negatif dengan harga ekspor karet alam Indonesia sementara harga karet alam internasional dan harga ekspor karet alam Indonesia tahun sebelumnya memiliki hubungan yang positif terhadap harga ekspor karet alam Indonesia. Kenaikan total ekspor karet alam akan menyebabkan kelebihan penawaran karet 
alam di pasar dunia yang akan mendorong penurunan harga karet alam internasional yang akan ditransmisikan kepada harga ekspor karet alam Indonesia. Hal ini sesuai dengan penelitian Prabowo (2017) yang menyebutkan bahwa penawaran ekspor karet alam Indonesia akan mempengaruhi harga ekspor karet alam Indonesia dalam jangka panjang. Penelitian Tety (2002) memperkuat hasil penelitian ini, yaitu bahwa perubahan penawaran ekspor di negara eksportir akan direspon oleh harga ekspornya meskipun secara lamban. Berdasarkan hasil penelitian ini, maka kebijakan ITRC dalam pengendalian supply karet alam di pasar dunia dengan mengendalikan penawaran ekspor untuk meningkatkan harga seharusnya dapat memberi dampak kenaikan harga ekspor karet alam yang diharapkan. Sementara itu, harga karet alam internasional juga memberikan pengaruh signifikan kepada harga ekspor karet alam Indonesia pada taraf nyata $1 \%$. Hal ini menunjukan bahwa terjadi integrasi yang baik pada pasar karet alam dunia pada pasar karet alam di negara eksportirnya, termasuk di Indonesia. Penelitian Nurhidayati (2013) juga menyebutkan bahwa harga pasar fisik Indonesia memberi respon positif terhadap harga karet internasional di bursa SICOM dengan menunjukan pola perkembangan harga pasar fisik Indonesia searah dengan perkembangan harga di bursa SICOM.

Kebijakan peningkatan konsumsi karet alam domestik berdasar pada teori ekonomi dimana peningkatan permintaan akan meningkatkan harga barang. Berdasarkan kesepakatan DPS untuk meningkatkan permintaan domestik sebesar $10 \%$ per tahunnya, Indonesia melakukan berbagai upaya untuk menyerap karet alam domestik, yaitu dengan penggunaan karet alam sebagai bahan baku jalan raya di pulau jawa, Sumatera dan Kalimantan, pembangunan pabrik ban di sentra produksi karet serta penggunaan lainnya yang masih dalam tahap pengembangan, yaitu sebagai bangunan anti gempa dan lainnya. Analisis dampak simulasi penerapan kebijakan DPS dilakukan dengan skenario peningkatan konsumsi domestik karet alam Indonesia sebesar $10 \%$.
Berdasarkan hasil simulasi Lampiran 1, diketahui bahwa peningkatan konsumsi domestik Indonesia sebesar 10\%, berdampak langsung terhadap 2 variabel endogen lainnya, yaitu terhadap ekspor karet alam ke negara negara tujuan ekspor dan pada harga di tingkat produsen. Adanya peningkatan konsumsi karet alam domestik, memaksa kondisi pasar karet Indonesia yang selama ini bertumpu pada pasar ekspor untuk mengalihkan produksi untuk memenuhi kebutuhan dalam negeri, sehingga penawaran ekspor karet alam Indonesia ke negara tujuan ekspor mengalami penurunan dengan total sebesar $6,99 \%$. Adanya penurunan total ekspor akan berdampak pada peningkatan harga ekspor karet Indonesia dan penurunan ekspor karet dunia sebesar 2,06\%.

Penurunan penawaran karet di pasar dunia menyebabkan harga dunia terdorong naik sebesar 3,97\% dan akan ditransmisikan ke pasar fisik di masing - masing negara pengekspor dan pengimpor. Di negara - negara ITRC lainnya, peningkatan harga di pasar fisik karet Thailand sebesar 3,29\%, sementara di Malaysia sebesar $1,79 \%$. Hal ini berarti, harga di pasar fisik Thailand lebih sensitif terhadap guncangan yang terjadi di bursa SICOM dibandingkan pasar fisik di Malaysia. Dampak peningkatan harga tersebut, menjadi reaktor bagi eksportir Thailand dan Malaysia untuk meningkatkan jumlah ekspornya masing - masing sebesar 1,33\% dan $0,01 \%$. Dilihat dari angka tersebut, diketahui bahwa Thailand lebih responsif terhadap perubahan harga ekspor dibandingkan Malaysia. Hal tersebut disebabkan oleh kondisi pasar karet alam di Thailand yang lebih mengutamakan pasar ekspor, sementara hal tersebut tidak berlaku bagi Malaysia yang memasarkan karet alamnya ke pasar dunia sebesar $25 \%$. Sementara itu, di pasar fisik masing - masing negara importir juga mengalami kenaikan harga, yaitu di Tiongkok sebesar 1,82\%, di AS sebesar $2,39 \%$ dan di Jepang sebesar 1,84\%. Adanya peningkatan harga impor, direspon oleh importir karet alam di masing - maisng negara importir untuk menurunkan permintaan impornya. Di tiongkok terjadi penurunan permintaan impor sebesar 0,24\%, sementara di AS dan Jepang penurunan permintaan impor masing - masing adalah $1,73 \%$ dan $1,72 \%$. 
Tabel 1. Dampak penerapan kebijakan ITRC terhadap distribusi kesejahteraan tahun 2007-2017

\begin{tabular}{cccc}
\hline & Surplus Produsen (Juta Rp) & $\begin{array}{c}\text { Surplus Exportir } \\
\text { (Juta Rp) }\end{array}$ & $\begin{array}{c}\text { Total Surplus } \\
\text { (Juta Rupiah) }\end{array}$ \\
\hline SIMULASI 1 & $1,167,605,206.00$ & $(364,469,372.00)$ & $803,135,834.00$ \\
SIMULASI 2 & $1,239,435,781.00$ & $(735,208,525.00)$ & $504,227,256.00$ \\
SIMULASI 3 & $1,049,985,238.00$ & $1,283,720,213.00$ & $2,333,705,451.00$ \\
SIMULASI 4 & $1,829,589,009.00$ & $3,382,606,806.00$ & $5,212,195,815.00$ \\
SIMULASI 5 & $1,087,140,428.00$ & $1,404,684,083.00$ & $2,491,824,511.00$ \\
SIMULASI 6 & $1,941,413,152.00$ & $3,667,035,364.00$ & $5,608,448,516.00$ \\
SIMULASI 7 & $2,094,499,624.00$ & $4,160,698,722.00$ & $6,255,198,346.00$ \\
SIMULASI 8 & $2,717,530,070.00$ & $6,972,291,355.00$ & $9,689,821,425.00$ \\
\hline
\end{tabular}

Keterangan :

Simulasi 1 = penurunan produksi karet alam Indonesia $20 \%$

Simulasi 2 = peningkatan konsumsi karet alam domestik $10 \%$

Simulasi 3 = penurunan penawaran ekspor karet alam dari Indonesia 3\%

Simulasi 4 = penurunan penawaran ekspor karet alam dari Indonesia 3\% dan Thailand 5\%

Simulasi 5 = penurunan penawaran ekspor karet alam Indonesia 3\% dan Malaysia 2\%

Simulasi 6 = penurunan penawaran ekspor dari negara anggota ITRC $10 \%$

Simulasi 7 = kombinasi antara penurunan produksi karet $20 \%$, peningkatan konsumsi domestik $10 \%$ dan menurunan penawaran ekspor Indonesia sebesar 3\%

Simulasi $8=$ kombinasi antara penurunan produksi karet 20\%, peningkatan konsumsi domestik $10 \%$ dan penurunan penawaran ekspor dari negara - negara ITRC sebesar $10 \%$

Pada akhirnya, dari simulasi ini terlihat bahwa peningkatan konsumsi karet alam domestik, akan menyebabkan peningkatan harga karet alam di tingkat produsen sebesar $5.33 \%$ yang merupakan dampak adanya peningkatan konsumsi domestik serta transmisi harga ekspor karet Indonesia yang meningkat. Dilihat dari simulasi 1 , bahwa peningkatan harga di tingkat produsen tidak sebesar yang diperoleh saat adanya penurunan produksi. Namun demikian, peningkatan konsumsi domestik tidak membawa resiko bagi petani, bahwa petani dapat meningkatkan produksinya sebagai dampak dari peningkatan harga tersebut. Selain itu, hal ini juga membantu memperkuat posisi tawar petani karena memiliki alternatif dalam menjual hasil produksi karetnya. Hal ini tergambar dari gap peningkatan harga, dimana pada simulasi ini terjadi peningkatan harga lebih tinggi terjadi di tingkat produsennya $(5,3 \%)$, sementara di tingkat eksportirnya hanya $5,2 \%$.

Penerapan peningkatan konsumsi karet alam domestik membawa dampak peningkatan kesejahteraan petani dilihat dari analisa surplus produsennya yaitu sebesar Rp. 1.239.435.781. 000,00 untuk seluruh petani karet Indonesia (Tabel 1). Dengan asumsi bahwa jumlah petani karet Indonesia berjumlah sekitar 2,5 juta jiwa (Direktorat Jenderal Perkebunan, 2018), maka bagi satu orang petani akan mendapatkan surplus sebesar RP. 495.374,00/tahun.

\section{KESIMPULAN}

Kebijakan peningkatan konsumsi karet alam domestik sebesar $10 \%$ dapat meningkatkan kesejahteraan petani karet alam Indonesia. Adanya kebijakan ini dapat memberikan keuntungan bagi petani karena dapat meningkatkan bargaining position petani dengan meningkatnya permintaan karet domestik. Oleh sebab itu, pemerintah disarankan segera menerapkan upaya penguatan regulasi terintegrasi antar kementerian terkait penyerapan konsumsi karet dalam negeri, misalnya regulasi tentang penggunaan karet alam sebagai bahan baku pembuatan jalan dan infrastruktur lainnya. Selain itu, kebijakan DPS merupakan kebijakan yang tepat dalam memasuki era industri 4.0 sektor hulu (upstream) dan antara (midstream) karet masih sangat lemah. Oleh sebab itu, untuk peningkatan konsumsi karet dalam negeri, komoditi karet sebaiknya menjadi sektor prioritas revolusi industri 4.0.

\section{DAFTAR PUSTAKA}

Direktorat Jenderal Perkebunan. (2018). Statistik Perkebunan Indonesia 2015 2017: Karet [internet]. Retrieved from http://ditjenbun.pertanian.go.id 
Gabungan Perusahaan Karet Indonesia. (2019). Informasi Pasar dan Perkembangan Karet. Retrieved from https://gapkindo.org/.

Ginting, A. M. (2013). Pengaruh Nilai Tukar Terhadap Ekspor Indonesia. Buletin Ilmiah Litbang Perdagangan, 7(1).

Harder, M. (2018). Natural Rubber Vs Synthetic Rubber - The Price Relationship and Demand Switchability [internet]. Retrieved February 19, 2019, from https://www.halcyonagri.com/natur al-rubber-vs-synthetic-rubber-the-pricerelationship-and-demand-switchability/

Indonesia Eximbank Institute. (2019). Proyeksi Ekspor Berdasarkan Industri: Komoditas Unggulan. Jakarta: Indonesia Eximbank.

Kementan. (2020). Kementerian Pertanian DATA LIMA TAHUN TERAKHIR. Retrieved April 17, 2020, from https://www.pertanian.go.id/home/?show $=$ page $\&$ act $=$ view $\&$ id $=61$

Nurhidayati, I. (2013). Analisis integrasi pasar karet alam antara produsen utama dengan pasar berjangka Singapura dan Jepang [Tesis]. Bogor.
Prabowo, Y. (2017). Analisis permintaan ekspor karet alam Indonesia ke negara China, Jepang, Kanada dan Amerika Serikat [Tesis]. Yogyakarta.

Pusat Data dan Sitem Informasi Pertanian. (2017). Outlook Komoditas Pertanian subsektor Perkebunan. Jakarta: Kementerian Pertanian.

Simatupang, P. (2007). Analisis Kritis terhadap Paradigma dan Kerangka Dasar Kebijakan Ketahanan Pangan Nasional. Jurnal Forum Penelitian Agro Ekonomi, 25(1), 1-18.

Sinaga, B. M. (1989). Econometric model of the Indonesian hardwood products industry. A Simulation Policy Analysis [Dissertation]. Los Banos.

Tety, E. (2002). Penawaran permintaan karet alam Indonesia di pasar domestik dan internasional [Tesis]. Bogor.

Welatama, A. (2017). Dampak Kebijakan International Tripartite Rubber Council dalam Membatasi Kuota Ekspor Karet Alam terhadap Indonesia. JOM FISIP, 4(2), 1-8. 
Lampiran 1. Model Analisis Simultan yang digunakan dalam analisis kesejahteraan

\section{Area Menghasilkan Karet Alam}

\section{Blok Karet Alam Indonesia}

$\mathrm{AKI}_{\mathrm{t}}=\mathrm{a}_{0}+\mathrm{a}_{1}$ PPKI $_{\mathrm{t}}+\mathrm{a}_{2}\left(\mathrm{PDSI}_{\mathrm{t}} / \mathrm{PDSI}_{\mathrm{t}-1}\right)+\mathrm{a}_{3}\left(\mathrm{PPU}_{\mathrm{t}}-\mathrm{PPU}_{\mathrm{t}-1}\right)+\mathrm{a}_{4} \mathrm{AKI}_{\mathrm{t}-1}+\mathrm{U}_{1}$

Tanda parameter yang diharapkan (hipotesis): $\mathrm{a}_{1}>0 ; \mathrm{a}_{2}, \mathrm{a}_{3}<0 ; 0<\mathrm{a}_{4}<1$

Keterangan :

$\mathrm{AKI}_{\mathrm{t}} \quad=$ Areal karet menghasilkan Indonesia pada tahun ke-t $(\mathrm{Ha})$

$\mathrm{PPKI}_{\mathrm{t}} \quad=$ Harga riil karet di tingkat produsen Indonesia pada tahun ke-t $(\mathrm{Rp} / \mathrm{kg})$

PDSI $_{\mathrm{t}} \quad=$ Harga riil sawit di tingkat produsen Indonesia pada tahun ke-t $(\mathrm{Rp} / \mathrm{kg})$

PDSI $_{\mathrm{t}-1}=$ Harga riil sawit di tingkat produsen Indonesia pada tahun sebelumnya $(\mathrm{Rp} / \mathrm{kg})$

$\mathrm{PPU}_{\mathrm{t}} \quad=$ Harga riil pupuk urea Indonesia pada tahun ke-t $(\mathrm{Rp} / \mathrm{kg})$

$\mathrm{PPU}_{\mathrm{t}-1} \quad=$ Harga riil pupuk urea Indonesia pada tahun sebelumnya $(\mathrm{Rp} / \mathrm{kg})$

AKI $_{\mathrm{t}-1}=$ Areal karet menghasilkan Indonesia pada tahun sebelumnya $(\mathrm{Ha})$

$\mathrm{a}_{0} \quad=$ Intersep

$\mathrm{a}_{\mathrm{i}} \quad=$ Parameter yang diduga $(\mathrm{i}=1,2,3,4, \ldots, \mathrm{n})$

$\mathrm{U}_{1} \quad=$ Variabel pengganggu

Produksi Karet Alam Indonesia

$\mathrm{QPKI}_{\mathrm{t}}=\mathrm{b}_{0}+\mathrm{b}_{1} \mathrm{AKI}_{\mathrm{t}}+\mathrm{b}_{2} \mathrm{PPKI}_{\mathrm{t}}+\mathrm{b}_{3} \mathrm{CHI}_{\mathrm{t}}+\mathrm{b}_{4} \mathrm{UPI}_{\mathrm{t}-1}+\mathrm{U}_{2}$

Tanda parameter yang diharapkan: $b_{1}, b_{2}, b_{3}>0 ; b_{4}<0$

Keterangan :

$\mathrm{QPKI}_{\mathrm{t}}=$ Produksi karet Indonesia tahun ke-t (ton/ha)

$\mathrm{AKI}_{\mathrm{t}} \quad=$ Areal karet menghasilkan Indonesia pada tahun ke-t $(\mathrm{Ha})$

$\mathrm{PPKI}_{\mathrm{t}} \quad=$ Harga karet alam di tingkat produsen pada tahun ke-t $(\mathrm{Rp} / \mathrm{kg})$

$\mathrm{CHI}_{\mathrm{t}} \quad=$ Curah hujan Indonesia tahun ke-t $(\mathrm{mm} / \mathrm{h})$

$\mathrm{UPI}_{\mathrm{t}-1}=$ Upah riil tenaga kerja Indonesia di sektor perkebunan pada tahun sebelumnya (Rp/bulan)

$\mathrm{b}_{0} \quad=$ Intersep

$\mathrm{b}_{\mathrm{i}} \quad=$ Parameter yang diduga $(\mathrm{i}=1,2,3,4, \ldots, \mathrm{n})$

$\mathrm{U}_{2} \quad=$ Variabel pengganggu

Produksitivitas Karet Indonesia

$\mathrm{YKI}_{\mathrm{t}} \quad=\mathrm{QPKI}_{\mathrm{t}} / \mathrm{AKI}_{\mathrm{t}}$

Keterangan :

QPKI $_{\mathrm{t}}=$ Produksi karet Indonesia pada tahun ke-t (ton)

$\mathrm{AKI}_{\mathrm{t}} \quad=$ Areal karet menghasilkan Indonesia pada tahun ke-t $(\mathrm{Ha})$

$\mathrm{YKI}_{\mathrm{t}} \quad=$ Produktivitas karet Indonesia tahun ke-t (ton/ha)

Penawaran Karet Alam Domestik

$\mathrm{QSK}_{\mathrm{t}}=\mathrm{QPKI}_{\mathrm{t}}+\mathrm{SK}_{\mathrm{t}-1}+\mathrm{MKI}_{\mathrm{t}}-\mathrm{XKI}_{\mathrm{t}}$

Keterangan :

QSK $_{\mathrm{t}} \quad=$ Jumlah penawaran karet alam di pasar domestik pada tahun ke-t (ton)

$\mathrm{QPKI}_{\mathrm{t}} \quad=$ Produksi karet Indonesia pada tahun ke-t (ton)

$\mathrm{SK}_{\mathrm{t}-1}=$ Stok karet alam domestik pada tahun lalu (ton)

$\mathrm{MKI}_{\mathrm{t}} \quad=$ Jumlah impor karet alam Indonesia pada tahun ke-t (ton)

$\mathrm{XKI}_{\mathrm{t}} \quad=$ Jumlah ekspor karet alam Indonesia pada tahun ke-t (ton) 
Permintaan Karet Alam Domestik

$\mathrm{QDK}_{\mathrm{t}}=\mathrm{c}_{0}+\mathrm{c}_{1} \mathrm{PKSI}_{\mathrm{t}}+\mathrm{c}_{2} \mathrm{PBD}_{\mathrm{t}}+\mathrm{c}_{3} \mathrm{GDP}_{\mathrm{t}}+\mathrm{c}_{4} \mathrm{PPKI}_{\mathrm{t}}+\mathrm{c}_{5} \mathrm{QDK}_{\mathrm{t}-1}+\mathrm{U}_{3}$

Tanda parameter dugaan yang diharapkan adalah :

$\mathrm{c}_{1}, \mathrm{c}_{2}, \mathrm{c}_{3}>0 ; \mathrm{c}_{4}<0 ; 0<\mathrm{c}_{5}<1$

Keterangan :

$\mathrm{QDK}_{\mathrm{t}} \quad=$ Jumlah permintaan karet alam domestik pada tahun ke-t (ton)

$\mathrm{PKSI}_{\mathrm{t}} \quad=$ Harga riil karet sintetis Indonesia pada tahun ke-t $(\mathrm{Rp} / \mathrm{Kg})$

$\mathrm{QBD}_{\mathrm{t}} \quad=$ Produksi ban domestik pada tahun ke-t (Rp/unit)

$\mathrm{GDP}_{\mathrm{t}} \quad=$ GDP riil Indonesia pada tahun ke-t $(\mathrm{Rp})$

$\mathrm{PPKI}_{\mathrm{t}} \quad=$ Harga riil karet alam di tingkat produsen $(\mathrm{Rp} / \mathrm{Kg})$

$\mathrm{QDK}_{\mathrm{t}-1}=$ Jumlah permintaan karet alam domestik pada tahun sebelumnya (ton)

$\mathrm{c}_{0} \quad=$ Intersep

$\mathrm{c}_{\mathrm{i}} \quad=$ Parameter yang diduga $(\mathrm{i}=1,2,3,4, \ldots, \mathrm{n})$

$\mathrm{U}_{3} \quad=$ Variabel pengganggu

Harga Karet Alam Di Tingkat Produsen

PPKI $_{\mathrm{t}}=\mathrm{d}_{0}+\mathrm{d}_{1} \mathrm{PXKI}_{\mathrm{t}}+\mathrm{d}_{2} \mathrm{ERI}_{\mathrm{t}}+\mathrm{d}_{3}\left(\mathrm{QDK}_{\mathrm{t}}-\mathrm{QDK}_{\mathrm{t}-1}\right)+\mathrm{d}_{4} \mathrm{QSK}_{\mathrm{t}}+\mathrm{d}_{5} \mathrm{PPKI}_{\mathrm{t}-1}+\mathrm{U}_{4}$

Tanda parameter dugaan yang diharapkan adalah :

$\mathrm{d}_{1}, \mathrm{~d}_{2}, \mathrm{~d}_{3}>0 ; \mathrm{d}_{4}<1 ; 0<\mathrm{d}_{5}<1$

Keterangan :

$\mathrm{PPKI}_{\mathrm{t}} \quad=$ Harga riil karet alam di tingkat petani pata tahun ke-t $\mathrm{Rp} / \mathrm{Kg}$ )

PXKI $_{t}=$ Harga riil ekspor karet alam Indonesia pada tahun ke-t (US\$/ton)

ERI $_{\mathrm{t}} \quad=$ Nilai tukar rupiah terhadap US\$ riil pada tahun ke-t $(\mathrm{Rp} / \mathrm{US} \$)$

QDK $_{\mathrm{t}} \quad=$ Jumlah permintaan karet alam domestik pada tahun ke-t (ton)

QDK $_{\mathrm{t}-1}=$ Jumlah permintaan karet alam domestik pada tahun sebelumnya (ton)

QSK $_{\mathrm{t}} \quad=$ Jumlah penawaran karet alam domestik pada tahun ke-t (ton)

$\mathrm{PPKI}_{\mathrm{t}-1}=$ Harga riil karet alam di tingkat petani pada tahun sebelumnya $(\mathrm{Rp} / \mathrm{Kg})$

$\mathrm{d}_{0} \quad=$ Intersep

$\mathrm{d}_{\mathrm{i}} \quad=$ Parameter yang diduga $(\mathrm{i}=1,2,3,4, \ldots, \mathrm{n})$

$\mathrm{U}_{4} \quad=$ Variabel pengganggu

Ekspor Karet Alam Indonesia

XKASt $=\mathrm{e}_{0}+\mathrm{e}_{1}\left(\mathrm{QPKI}_{\mathrm{t}}-\mathrm{QPKI}_{\mathrm{t}-1}\right)+\mathrm{e}_{2}\left(\mathrm{PXKI}_{\mathrm{t}}-\mathrm{PXKI}_{\mathrm{t}-1}\right)+\mathrm{e}_{3} \mathrm{ERIt}+\mathrm{e}_{4} \mathrm{QDK}_{\mathrm{t}}+\mathrm{U}_{5}$

XKTKt $=\mathrm{f}_{0}+\mathrm{f}_{1} \mathrm{QPKI}_{\mathrm{t}}+\mathrm{f}_{2}\left(\mathrm{PXKI}_{\mathrm{t}}-\mathrm{PXKI}_{\mathrm{t}-1}\right)+\mathrm{f}_{3} \mathrm{ERIt}_{\mathrm{f}}+\mathrm{f}_{4} \mathrm{QDK}_{\mathrm{t}}+\mathrm{U}_{6}$

$\mathrm{XKJPt}=\mathrm{g}_{0}+\mathrm{g}_{1} \mathrm{QPKI}_{\mathrm{t}}+\mathrm{g}_{2}\left(\mathrm{PXKI}_{\mathrm{t}}-\mathrm{PXKI}_{\mathrm{t}-1}\right)+\mathrm{g}_{3}$ ERIt $+\mathrm{g}_{4} \mathrm{QDK}_{\mathrm{t}}+\mathrm{U}_{7}$

Tanda parameter yang diharapkan:

$\mathrm{e}_{1}, \mathrm{e}_{2}, \mathrm{e}_{3}>0 ; \mathrm{e}_{4}<0$

$\mathrm{f}_{1}, \mathrm{f}_{2}, \mathrm{f}_{3}>0 ; \mathrm{f}_{4}<0$

$\mathrm{g}_{1}, \mathrm{~g}_{2}, \mathrm{~g}_{3}>0 ; \mathrm{g}_{4}<0$

Keterangan :

XKASt $=$ Jumlah ekspor karet alam Indonesia ke Amerika Serikat pada tahun ke-t (ton)

XKTKt = Jumlah ekspor karet alam Indonesia ke Tiongkok pada tahun ke-t (ton)

XKJPt $=$ Jumlah ekspor karet alam Indonesia ke Jepang pada tahun ke-t (ton)

QPKI $_{\mathrm{t}}=$ Produksi karet Indonesia pada tahun ke-t (ton)

$\mathrm{QPKI}_{\mathrm{t}-1}=$ Produksi karet Indonesia pada tahun sebelumnya (ton)

$\mathrm{PXKI}_{\mathrm{t}} \quad=$ Harga ekspor karet alam Indonesia pada tahun ke-t (US\$/ton)

$\mathrm{PXKI}_{\mathrm{t}-1}=$ Harga ekspor karet alam Indonesia pada tahun sebelumnya (US\$/ton) 


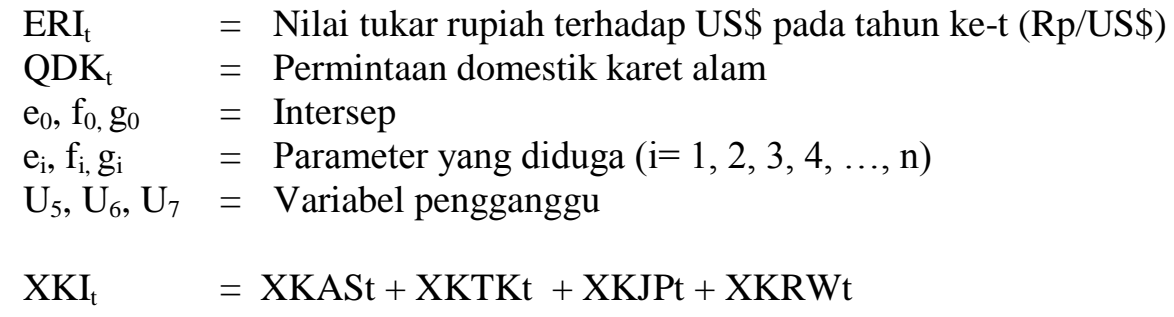

Keterangan :

$\mathrm{XKI}_{\mathrm{t}} \quad=$ Total ekspor karet alam Indonesia pada tahun ke-t(ton)

XKASt $=$ Jumlah ekspor karet alam Indonesia ke Amerika Serikat pada tahun ke-t (ton)

XKTKt = Jumlah ekspor karet alam Indonesia ke Tiongkok pada tahun ke-t (ton)

$\mathrm{XKJPt}=$ Jumlah ekspor karet alam Indonesia ke Jepang pada tahun ke-t (ton)

$\mathrm{XKRWt}=$ Jumlah ekspor karet alam Indonesia ke sisa dunia tahun ke-t (ton)

Harga Ekspor Karet Alam Indonesia

PXKI $_{\mathrm{t}}=\mathrm{h}_{0}+\mathrm{h}_{1} \mathrm{XKI}_{\mathrm{t}}+\mathrm{h}_{2} \mathrm{PKW}_{\mathrm{t}}+\mathrm{h}_{3} \mathrm{PXKI}_{\mathrm{t}-1}+\mathrm{U}_{8}$

Tanda parameter yang diharapkan :

$\mathrm{h}_{1}, \mathrm{~h}_{2}>0 ; 0<\mathrm{h}_{3}<1$

Keterangan :

$\mathrm{PXKI}_{\mathrm{t}}=$ Harga ekspor karet alam Indonesia pada tahun ke-t $(\mathrm{Rp} / \mathrm{kg})$

$\mathrm{XKI}_{\mathrm{t}} \quad=$ Total ekspor karet alam Indonesia pada tahun ke-t (ton)

$\mathrm{PKW}_{\mathrm{t}} \quad=$ Harga riil karet alam dunia pada tahun ke-t $(\mathrm{US} \$ / \mathrm{kg})$

$\mathrm{PXKI}_{\mathrm{t}-1}=$ Harga riil ekspor karet alam Indonesia pada tahun sebelumnya $(\mathrm{Rp} / \mathrm{kg})$

$\mathrm{h}_{0} \quad=$ Intersep

$\mathrm{h}_{\mathrm{i}} \quad=$ Parameter yang diduga $(\mathrm{i}=1,2,3,4, \ldots, \mathrm{n})$

$\mathrm{U}_{8} \quad=$ Variabel pengganggu

Blok Karet Alam Negara I
Penawaran Ekspor Karet Alam Negara ITRC lainnya

$\mathrm{XKTH}_{\mathrm{t}}=\mathrm{i}_{0}+\mathrm{i}_{1} \mathrm{PXKTH}_{\mathrm{t}}+\mathrm{i}_{2} \mathrm{QPKTH}_{\mathrm{t}}+\mathrm{i}_{3} \mathrm{ERTH}_{\mathrm{t}}+\mathrm{U}_{9}$

$\mathrm{XKMY}_{\mathrm{t}}=\mathrm{j}_{0}+\mathrm{j}_{1}\left(\mathrm{PXKMY}_{\mathrm{t}}-\mathrm{PXKMY}_{\mathrm{t}-1}\right)+\mathrm{j}_{2} \mathrm{QPKMY}_{\mathrm{t}}+\mathrm{j}_{3} \mathrm{XKMY}_{\mathrm{t}-1}+\mathrm{U}_{10}$

Tanda parameter yang diharapkan:

$\mathrm{i}_{1}, \mathrm{i}_{2}, \mathrm{i}_{3}>0$

$\mathrm{j}_{1}, \mathrm{j}_{2}>0 ; 0<\mathrm{j}_{3}<1$

Keterangan :

$\mathrm{XKTH}_{\mathrm{t}}=$ Jumlah ekspor karet alam Thailand pada tahun ke-t (ton)

$\mathrm{XKMY}_{\mathrm{t}}=$ Jumlah ekspor karet alam Malaysia pada tahun ke-t (ton)

PXKTH $_{\mathrm{t}}=$ Harga riil ekspor karet alam Thailand pada tahun ke-t (US\$/ton)

PXKMY $_{\mathrm{t}}=$ Harga riil ekspor karet alam Malaysia pada tahun ke-t (US\$/ton)

$\mathrm{PXKMY}_{\mathrm{t}-1}=$ Harga riil ekspor karet alam Malaysia pada tahun sebelumnya (US\$/ton)

QPKTH $_{\mathrm{t}}=$ Jumlah produksi karet alam Thailand pada tahun ke-t (ton)

QPKMY $_{\mathrm{t}}=$ Jumlah produksi karet alam Malaysia pada tahun ke-t (ton)

ERTH $_{\mathrm{t}}=$ Nilai tukar Bath terhadap US\$ pada tahun ke-t

$\mathrm{XKMY}_{\mathrm{t}-1}=$ Jumlah ekspor karet alam Malaysia pada tahun sebelumnya (ton)

$\mathrm{i}_{0}, \mathrm{j}_{0} \quad=$ Intersep

$\mathrm{i}_{\mathrm{i}}, \mathrm{j}_{\mathrm{i}} \quad=$ Parameter yang diduga $(\mathrm{i}=1,2,3,4, \ldots, \mathrm{n})$

$\mathrm{U}_{9}, \mathrm{U}_{10}=$ Variabel pengganggu 


\section{Harga Ekspor Karet Alam Negara ITRC lainnya}

$\mathrm{PXKTH}_{\mathrm{t}}=\mathrm{k}_{0}+\mathrm{k}_{1} \mathrm{PKW}_{\mathrm{t}}+\mathrm{k}_{2} \mathrm{PXKTH}_{\mathrm{t}-1}+\mathrm{U}_{11}$

PXKMY $_{\mathrm{t}}=1_{0}+1_{1} \mathrm{PKW}_{\mathrm{t}}+1_{2} \mathrm{PXKMY}_{\mathrm{t}-1}+\mathrm{U}_{12}$

Tanda parameter yang diharapkan:

$\mathrm{k}_{1}>0 ; 0<\mathrm{j}_{2}<1$

$1_{1}>0 ; 0<1_{2}<1$

Keterangan :

$\mathrm{PXKTH}_{\mathrm{t}}=$ Harga riil ekspor karet alam Thailand pada tahun ke-t (US\$/ton)

$\mathrm{PXKMY}_{\mathrm{t}}=$ Harga riil ekspor karet alam Malaysia pada tahun ke-t (US\$/ton)

$\mathrm{PKW}_{\mathrm{t}} \quad=$ Harga riil karet alam dunia (US\$/ton)

PXKTH $_{\mathrm{t}-1}=$ Harga riil ekspor karet alam Thailand pada tahun sebelumnya (US\$/ton)

$\mathrm{PXKMY}_{\mathrm{t}-1}=$ Harga riil ekspor karet alam Malaysia pada tahun sebelumnya (US\$/ton)

$\mathrm{k}_{\mathrm{i}}, \mathrm{l}_{\mathrm{i}} \quad=$ Parameter yang diduga $(\mathrm{i}=1,2,3,4, \ldots, \mathrm{n})$

$\mathrm{U}_{11}, \mathrm{U}_{12}=$ Variabel pengganggu

Penawaran karet alam dunia

$\mathrm{XKW}_{\mathrm{t}}=\mathrm{XKI}_{\mathrm{t}}+\mathrm{XKTH}_{\mathrm{t}}+\mathrm{XKMY}_{\mathrm{t}}+\mathrm{XKRW}_{\mathrm{t}}$

Keterangan :

$\mathrm{XKW}_{\mathrm{t}} \quad=$ Jumlah ekspor karet alam dunia pada tahun ke-t (ton)

$\mathrm{XKI}_{\mathrm{t}} \quad=$ Jumlah ekspor karet alam Indonesia pada tahun ke-t(ton)

$\mathrm{XKTH}_{\mathrm{t}} \quad=$ Jumlah ekspor karet alam Thailand pada tahun ke-t (ton)

$\mathrm{XKMY}_{\mathrm{t}}=$ Jumlah ekspor karet alam Malaysia pada tahun ke-t (ton)

$\mathrm{XKRW}_{\mathrm{t}} \quad=$ Jumlah ekspor karet alam sisa dunia pada tahun ke-t (ton)

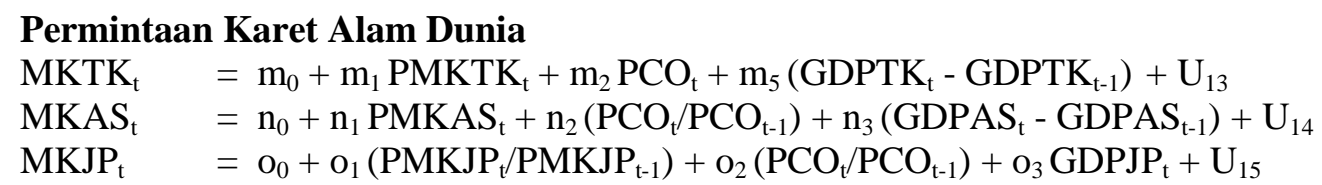

Adapun tanda parameter dugaan yang diharapkan :

$\mathrm{m}_{3}<0 ; \mathrm{m}_{2}, \mathrm{~m}_{3}>0$

$\mathrm{n}_{3}<0 ; \mathrm{n}_{2}, \mathrm{n}_{3}>0$

$\mathrm{O}_{3}<0 ; \mathrm{o}_{2}, \mathrm{O}_{3}>0$

Keterangan :

MKTK $_{\mathrm{t}} \quad=$ Jumlah impor karet alam oleh Tingkok pada tahun ke-t (ton)

MKAS $_{\mathrm{t}} \quad=$ Jumlah impor karet alam oleh Amerika Serikat pada tahun ke-t (ton)

MKJP $_{\mathrm{t}} \quad=$ Jumlah impor karet alam oleh Jepang pada tahun ke-t (ton)

PMKTK $_{\mathrm{t}} \quad=$ Harga riil impor karet alam di Tiongkok pada tahun ke-t $(\mathrm{US} \$ / \mathrm{Kg})$

PMKAS $_{\mathrm{t}} \quad=$ Harga riil impor karet alam di Amerika Serikat pada tahun ke-t $(\mathrm{US} \$ / \mathrm{Kg})$

PMKJP $_{\mathrm{t}} \quad=$ Harga riil impor karet alam di Jepang pada tahun ke-t $(\mathrm{US} \$ / \mathrm{Kg})$

$\mathrm{PMKJP}_{\mathrm{t}-1} \quad=$ Harga riil impor karet alam di Jepang pada tahun sebelumnya (US\$/Kg)

$\mathrm{PCO}_{\mathrm{t}} \quad=$ Harga minyak mentah dunia pada tahun ke-t (US\$/barel)

GDPTK $_{\mathrm{t}} \quad=$ GDP Tiongkok pada tahun ke-t (US\$)

GDPTK $_{\mathrm{t}-1}=$ GDP Tiongkok pada tahun sebelumnya (US\$)

GDPAS $_{\mathrm{t}} \quad=$ GDP Amerika Serikat pada tahun ke-t (US\$)

GDPAS $_{\mathrm{t}-1}=$ GDP Amerika Serikat pada tahun sebelumnya (US\$)

GDPJP $_{\mathrm{t}} \quad=$ GDP Jepang (Yen) pada tahun ke-t

$\mathrm{m}_{\mathrm{i}}, \mathrm{n}_{\mathrm{i}}, \mathrm{O}_{\mathrm{i}} \quad=$ Parameter yang diduga $(\mathrm{i}=1,2,3,4, \ldots, \mathrm{n})$ 
$\mathrm{U}_{13}, \mathrm{U}_{14}, \mathrm{U}_{15}=$ Variabel pengganggu

$\mathrm{MKW}_{\mathrm{t}}=\mathrm{MKTK}_{\mathrm{t}}+\mathrm{MKAS}_{\mathrm{t}}+\mathrm{MKJP}_{\mathrm{t}}+\mathrm{MKRW}_{\mathrm{t}}$

Keterangan :

$\mathrm{MKW}_{\mathrm{t}} \quad=$ Total impor karet alam dunia pada tahun ke-t (ton)

MKTK $_{\mathrm{t}} \quad=$ Jumlah impor karet alam oleh Tingkok pada tahun ke-t (ton)

MKAS $_{\mathrm{t}} \quad=$ Jumlah impor karet alam oleh Amerika Serikat pada tahun ke-t (ton)

MKJP $_{\mathrm{t}} \quad=$ Jumlah impor karet alam oleh Jepang pada tahun ke-t (ton)

MKRW $_{\mathrm{t}} \quad=$ Jumlah impor karet alam sisa dunia pada tahun ke-t (ton)

\section{Harga impor karet alam}

PMKTK $_{\mathrm{t}}=\mathrm{p}_{0}+\mathrm{p}_{1} \mathrm{PKW}_{\mathrm{t}}+\mathrm{p}_{2}$ PMKTK $_{\mathrm{t}-1}+\mathrm{U}_{16}$

PMKAS $_{\mathrm{t}} \quad=\mathrm{q}_{0}+\mathrm{q}_{1}$ PKW $_{\mathrm{t}}+\mathrm{q}_{2}$ PMKAS $_{\mathrm{t}-1}+\mathrm{U}_{17}$

PMKJP $_{\mathrm{t}} \quad=\mathrm{r}_{0}+\mathrm{r}_{1} \mathrm{PKW}_{\mathrm{t}}+\mathrm{r}_{2}$ PMKJP $_{\mathrm{t}-1}+\mathrm{U}_{18}$

Adapun tanda parameter dugaan yang diharapkan :

$\mathrm{p}_{1}>0 ; 0<\mathrm{p}_{2}<1$

$\mathrm{q}_{1}>0 ; 0<\mathrm{q}_{2}<1$

$\mathrm{r}_{1}>0 ; 0<\mathrm{r}_{2}<1$

Keterangan :

PMKTK $_{\mathrm{t}} \quad=$ Harga riil impor karet alam di Tiongkok pada tahun ke-t (US\$/ton)

PMKAS $_{\mathrm{t}} \quad=$ Harga riil impor karet alam di Amerika Serikat pada tahun ke-t (US\$/ton)

PMKJP $_{\mathrm{t}} \quad=$ Harga riil impor karet alam di Jepang pada tahun ke-t (US\$/ton)

$\mathrm{PKW}_{\mathrm{t}} \quad=$ Harga riil karet alam di pasar dunia pada tahun ke-t (US\$/ton)

PMKTK $_{\mathrm{t}-1}=$ Harga riil impor karet alam di Tiongkok pada tahun sebelumnya (US\$/ton)

PMKAS $_{\mathrm{t}-1}=$ Harga riil impor karet alam di Amerika Serikat pada tahun sebelumnya (US\$/ton)

$\mathrm{PMKJP}_{\mathrm{t}-1}=$ Harga riil impor karet alam di Jepang pada tahun sebelumnya (US\$/ton)

$\mathrm{p}_{\mathrm{i}}, \mathrm{q}_{\mathrm{i}}, \mathrm{r}_{\mathrm{i}} \quad=$ Parameter yang diduga $(\mathrm{i}=1,2,3,4, \ldots, \mathrm{n})$

$\mathrm{U}_{16}, \mathrm{U}_{17}, \mathrm{U}_{18}=$ Variabel pengganggu

\section{Harga karet alam dunia}

$\mathrm{PKW}_{\mathrm{t}}=\mathrm{s}_{0}+\mathrm{s}_{1}\left(\mathrm{MKW}_{\mathrm{t}} / \mathrm{MKW}_{\mathrm{t}-1}\right)+\mathrm{s}_{2}\left(\mathrm{XKW}_{\mathrm{t}}-\mathrm{XKW}_{\mathrm{t}-1}\right)+\mathrm{s}_{3} \mathrm{PKW}_{\mathrm{t}-1}+\mathrm{U}_{19}$

Tanda parameter yang diharapkan adalah :

$\mathrm{s}_{1}>0 ; \mathrm{s}_{2}<0 ; 0<\mathrm{s}_{3}<1$

Keterangan :

$\mathrm{PKW}_{\mathrm{t}} \quad=$ Harga riil karet alam di pasar dunia pada tahun ke-t(US\$/ton)

$\mathrm{MKW}_{\mathrm{t}} \quad=$ Total impor karet alam dunia pada tahun ke-t (ton)

$\mathrm{MKW}_{\mathrm{t}-1} \quad=$ Total impor karet alam dunia pada tahun sebelumnya (ton)

$\mathrm{XKW}_{\mathrm{t}} \quad=$ Jumlah ekspor karet alam dunia pada tahun ke-t (ton)

$\mathrm{XKW}_{\mathrm{t}} \quad=$ Jumlah ekspor karet alam dunia pada tahun sebelumnya (ton)

$\mathrm{PKW}_{\mathrm{t}-1} \quad=$ Harga riil karet alam di pasar dunia pada tahun sebelumnya (US\$/ton)

$\mathrm{s}_{\mathrm{i}} \quad=$ Parameter yang diduga $(\mathrm{i}=1,2,3,4, \ldots, \mathrm{n})$

$\mathrm{U}_{19} \quad=$ Variabel pengganggu 